\title{
ANIMAL HUSBANDRY OF SOUTH OF RUSSIA: CURRENT STATE AND PROSPECTS OF DEVELOPMENT
}

Elena Pismennaya, Vladimir Stucalo, Irina Volters, Lyudmila Kipa, Margarita Azarova

Stavropol State Agrarian University, Russia

pismennaya.elena@bk.ru, stukalo.vladimir@gmail.com,volters06@rambler.ru,kipa2014@inbox.ru, azarova778@gmail.com

\begin{abstract}
The leading branch of the South of Russia is crop production, which specializes in the cultivation of cereals and industrial crops, as well as sheep, meat and dairy cattle husbandry. Animal husbandry is a capitalintensive production with long investment cycles and relatively high risks. A crisis situation has developed in the region's animal husbandry: the number of all animal species has dramatically decreased, the livestock structure has changed in all categories of farms and problems have arisen with feed and their structural and nutritional imbalance. Thus, in the Stavropol Territory, the number of small ruminants tends to increase from 1428.8 to 2356.3 thousand heads. However, this number corresponds to unstable periods of the region development from 1916 till 1935 and from 1997 till 2014. For the period from 1999 till 2014 the number of cattle in the region did not significantly decrease (except for dairy cattle) and amounts to 389.9 thousand heads. At the same time, the dairy and meat products in the industry have decreased. In animal husbandry, only farms producing up to $80 \%$ of milk and meat remain competitive. However, the largest share of feed production account for large agricultural enterprises. The cost of livestock production and the gap in the rate of gain weight are growing constantly. That is why there is a lack of meat and dairy products. The volume of gross output for the period from 2005 till 2017 is provided by the domestic and foreign import of meat, which increased 3 times. The import of milk has decreased by 1.8 times. In order to recover industry, the government of the Stavropol Territory declared 2018 as the year of animal husbandry.
\end{abstract}

Keywords: agriculture, system of agricultural land use, land use, animal husbandry.

\section{Introduction}

The South of Russia is a unique natural area with a relatively high level of economic growth in agriculture. Realization of sustainable agrarian development in the region is not possible now due to poor formulation of structural and functional issues of the development sectors (sub-sectors) of crop and animal production.

Agricultural enterprises are characterized by a general trend of low livestock numbers and a small area of pastures and forage crop cultivation. The majority of pastures $(65.5 \%)$ are concentrated in large and medium-sized livestock enterprises. In these farms, significant areas of arable land were always allocated for forage crop cultivation, as the basis for formation of high animal productivity. Therefore, the systematic reduction of areas for multiyear grass is of particular concern. Over the past decades, their area has decreased by 2.5 times (from 173.9 to 69.2 thousand hectares), in the structure of crops by 3 times, crop yield by 3 times, the gross yield of perennial grasses for hay and green feed by 3.1 and 3.4 times, respectively (Fig. 1).

Therefore, modern livestock suffers from a lack of feed. Animal feed supplying in all farm categories of the region is 1278156 thousand tons of feed units, or 17.7 centners of feed units for a notional head, which is $50.6 \%$ of the needs [1]. In the livestock feed balance of the region more than $70 \%$ are roughages (hay, haylage, silage, green fodder), which are the basis of the farm animals' diet. However, harvesting of roughages is decreasing in the agricultural enterprises. There was a decrease in cultivation of roughage crops as well, with 732.5 million hectares between 1996 and 2000 to 299.2 thousand hectares in 2005. All this led to the fact that the amount of harvested fodder in agricultural enterprises decreased from 2277 thousand tons of feed units to 656.3 thousand tons of feed units between 1996 and 2000, to 293,5 thousand tons of feed units in 2005 and to 261,7 thousand tons of feed units in 2006 (not taking into account forages). Thus, the amount of fodder fell to the lowest level in the last 15 years [2]. As for certain types of harvested feed, the decline was as following: silage by 6.2 times, hay by 3.5 times, haylage by 7.5 times. Sharp decline in the number of ruminants in agricultural enterprises (from 1033 thousand heads in 1992, to 166.5 million heads in 2006) affected the fodder harvesting for a notional head of cattle: in 1992 it was 22 centers of feed units, in 2004 it was 22.4 centners of feed units, in 2005 it was 19.1 centners of feed units, in 2010 it was 11 centners of feed units, in 2017 it was 9.6 centners of feed units [3]. 


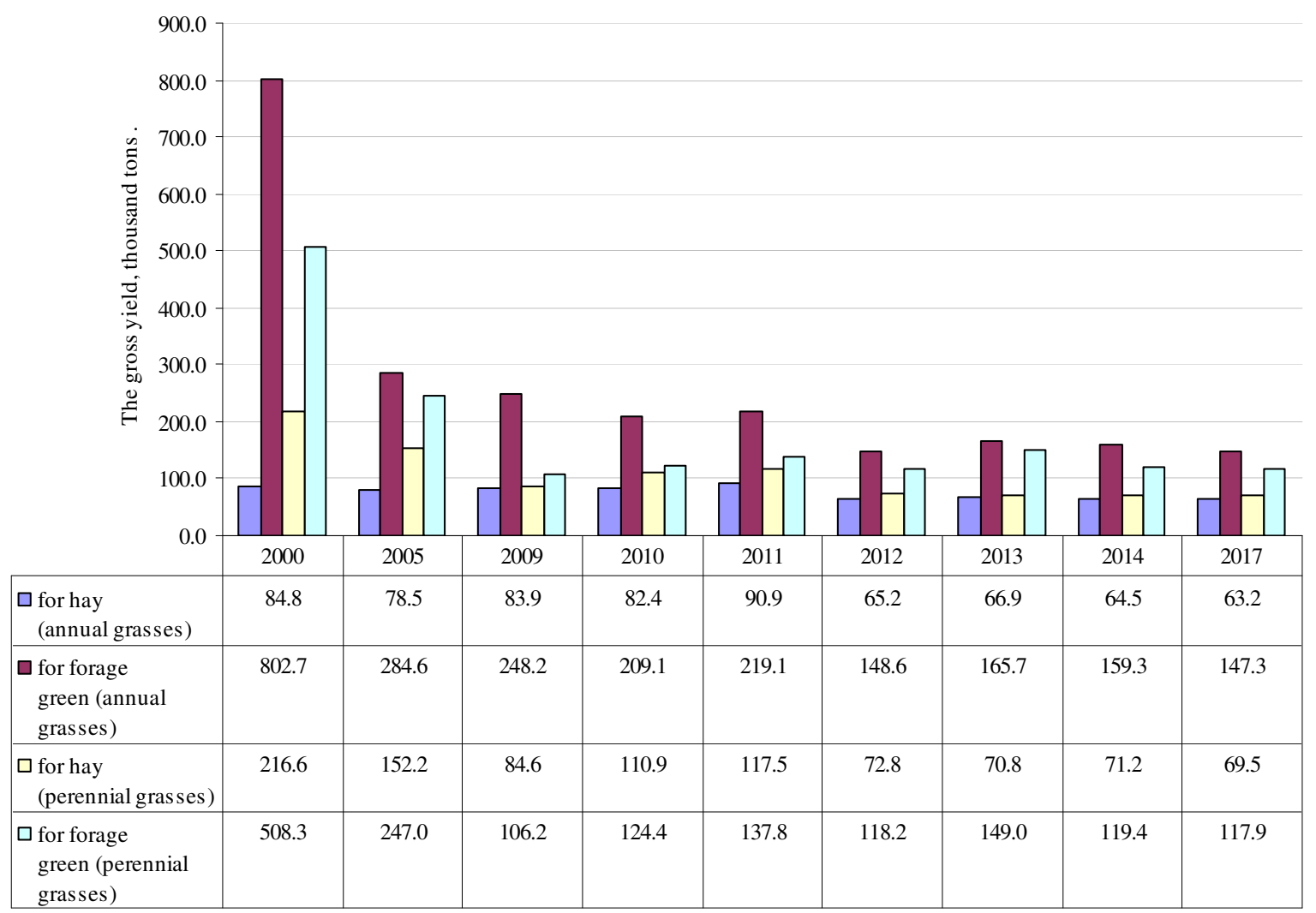

Fig. 1. Gross yield of annual and perennial grasses in agricultural enterprises of Stavropol Region, thousand tons

Pastures are a source of valuable and cheap green animal feed. Therefore, organization of their rational use is the most important task facing agricultural enterprises. The issues of the yield and quality of grass stand, its improvement, as well as productivity and capacity of natural forage lands are sufficiently represented in the domestic and foreign scientific literature [4-6]. There are no contours intended for nature protection purposes in the structure of agricultural enterprises, which is one of the reasons for degradation of forage lands caused by the lack of matter and energy transit (accumulation). And this leads to the structure and design damage of forage lands as natural systems. The issues of lands optimization and the recovery of their functions as self-regulating and self-replicating systems in the structural and functional model of agricultural enterprises in Russian science are reflected not fully and systemic, and require further research.

\section{Materials and methods}

Given scientific research of livestock development aims to identify regional patterns and relationships in the system "nature - economy", based on reports, records and statistical materials of industry conditions and use of natural resources. The described system, based on environmental and economic factors, ultimately affects the agricultural sustainability of the region and its enterprises. The aim of the current industry analysis is to identify new optimization ways of land use decisions on the example of a structural-functional formation model of agricultural enterprises oriented on creation of ecologically stable territories (by their economic zoning).

Domestic and foreign data [7-10] indicate that the optimal ratio establishment of industrial lands contributes to self-regulation of the natural area. However, this ratio in each specific case is individual and depends on the relief, soil, botanical, natural and economic conditions of the agricultural enterprise. It is achieved in the design process. The main features of the approach are to link the agricultural land to the elements of the territory organization and determine on this basis the regime and conditions of land use. 


\section{Results and discussion}

Today, in agricultural enterprises against the background of low productivity of 1 feed hectare of pastures (on average between 2001 and 2005 it was 15.8 centners of feed units), there was a shortage of protein and available energy in the produced fodder. The average nutritional values of $1 \mathrm{~kg}$ of roughage dry matter (without straw) is $25-30 \%$ lower than the recommended zootechnical animal feeding rates. Disturbance of the species structure of feed, its imbalance in nutrients led to a sharp, by 1.5 times, overrun of feed per unit production and a decrease in animal productivity.

The main reasons for the decrease of feed production and worsening of its quality are the reduction of the industry technical supply, destruction of the earlier established system of grasses seed-growing, work stoppage on improvement of natural grasslands, application of simplified cultivation technology in fodder crops, increase of the grassland degradation, etc. However, rational use of land, means of production and labor directly are associated with a scientifically based combination of fodder production industry with crop and livestock breeding.

The sharp decline in fodder production, the extensive system of production, the increase in the processes of land degradation necessitate the development of a comprehensive program of fodder production on the basis of agrophytocenoses modeling for each agricultural zone of the region. Intensive grazing is accompanied by the development of water and wind erosion, salinization, dehumification and other negative processes and phenomena. The current level of soil degradation is high. Therefore, the state programs should increase production of green fodder through the establishment of perennial cultivated pastures, which would supply up to $50 \%$ of the green feed requirements. This increase in the proportion of pasture fodder in the total fodder production will reduce the cost of the summer diet in 2.5-3.0 times and increase the profitability of livestock breeding. The main effect of grassland farming intensification is planned to obtain using the pasture rotation system; growing of varieties and species of perennial legumes and cereal grasses, maturing at different periods, in simple and complex grass mixtures; rational use of herbage through optimization of the harvesting time due to better technical means.

The region lacks practical experience in designing a structural-functional model of agricultural enterprises of animal husbandry in the form of the State Nature Reserve (SNR). The projected State Nature Reserve is organized as a transboundary object. Its territory includes lands, such as agricultural and forestry specially protected natural areas (SPNAs). The total area of the territory is 8546 hectares. The land use structure of the State Nature Reserve includes agricultural enterprises of grain-growing, livestock and hunting specialization, land of the rural administration, specially protected natural areas and the State Forest Fund (SFF) (Figure 2). The purpose of the land use development of the State Nature Reserve is presented in Table 1.

The goal of the project is, on the basis of ecological conditions, to restore and improve the pastures vegetation in accordance with their primary steppes vegetation. On overgrazing and newly created grasses, the share of legume-grass mixtures of fodder use should be increased to $72-75 \%$ in the general structure of sown and subsided grasses. Picking up both polyvidic and monovidic grass crops with a different period of use and taking into account the grain flowering phase on the multi-cut grass stands. On pastures to produce grazing at their height of $10-12 \mathrm{~cm}[4 ; 11]$.

Mixed crops of legume-grass are recommended when organizing a hay-pasture conveyor. For example, a 4-component mixture Russian wild ruttishness is 1.5 million seeds yield per 1 ha, crested wheat grass is 1.5 million, lucerne 2.0 million and North Caucasian sainfoin 2.5 million. The creation of seeded grass stands on the basis of multi-component legume-grass ensures productivity not lower than 4.0-4.2 thousand feed units from 1 ha. Capital investments in creating seeded grass stands will be paid off in the first year of application through the use of a cover crop (a two-year yellow sweet clover) as part of the grass mixture. Taking into account the period of the grass stand use (5 years of legume-grass and from 7 to 9 years of grass), the efficiency increases by 3-5 times. To reduce the capital investments in creation of natural forage lands, it is advisable to create long-term grass stands based on self-renewing species: awnless brome, orchard grass, meadow fescue grass, white clover, meadow bluegrass, Russian wild ruttishness, yellow and toothed medick. 


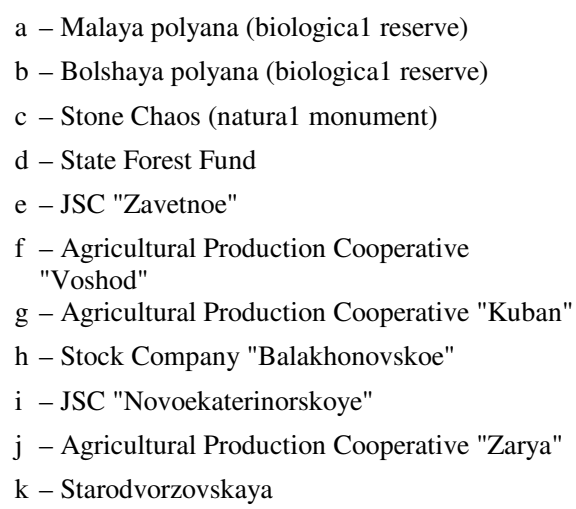

\begin{tabular}{|l|c|c|c|c|c|c|c|c|c|c|c|}
\hline$\square$ Natural-Reserved fund (profile) & 178 & 241 & 362 & 3660 & 0 & 0 & 0 & 0 & 0 & 0 & 0 \\
\hline $\begin{array}{c}\text { Agricultural enterprises, rural } \\
\text { administration }\end{array}$ & 0 & 0 & 0 & 0 & 1266 & 775 & 652 & 288 & 694 & 223 & 207 \\
\hline
\end{tabular}

Fig. 2. Structure of land fund forest-steppe SNR

Purpose of land use development of State Nature Reserve

\begin{tabular}{|c|c|c|}
\hline No & SNR structure & \multicolumn{1}{c|}{ Names / Purpose of organization } \\
\hline 1 & $\begin{array}{c}\text { The State Forest } \\
\text { Fund }\end{array}$ & $\begin{array}{l}\text { Stavropol forestry / Preservation of the genetic reserve of the State } \\
\text { Forest Fund. }\end{array}$ \\
\hline 2 & $\begin{array}{l}\text { "Stone Chaos" / Preservation of the natural massif of the eastern } \\
\text { beech and Caucasian hornbeam, relict plant species (bear's garlic, five- } \\
\text { leaved toothwort, cuckoo pint, pachyphragma macrophyllum, etc.) } \\
\text { "Malaya polyana" and "Bolshaya polyana" / Preservation of plant } \\
\text { species included in the Red Book of Russia (peach-leaved bellflower, rein } \\
\text { orchis, orchis picta, windflower, etc.), as well as four endemics of the } \\
\text { Caucasus (pea-tree, durmast oak, Caucasian snowdrop, ornithogalum } \\
\text { arcuatum) and the generic endemic pachyphragma macrophyllum. } \\
\text { Preservation of the animal world included in the Red Book of Russia } \\
\text { (black stork, steppe eagle, imperial eagle, little bustard, marbled polecat), } \\
\text { as well as local endemics. }\end{array}$ \\
\hline $\begin{array}{c}\text { Natural-Reserved } \\
\text { Fund }\end{array}$ & $\begin{array}{l}\text { JSC "Zavetnoe", Agricultural Production Cooperative "Voskhod", } \\
\text { Agricultural Production Cooperative "Kuban", Stock Company } \\
\text { "Balakhonovskoe", JSC "Novoekaterinovskoye" Agricultural Production } \\
\text { Cooperative "Zarya"/ Preservation of numerous species of cereal and } \\
\text { legume associations of foothill hydrophilic and xerophytic meadow } \\
\text { steppe (16 species including wheat grass, fescue grass, brome grass, } \\
\text { lucerne, etc.). Preservation of numerous species of cereal and legume } \\
\text { associations of foothill hydrophilic and xerophytic meadow steppe, as } \\
\text { well as game-hunting animals (wild boar, roe deer, fox, brown hare) }\end{array}$ \\
\hline 4 & $\begin{array}{l}\text { Starodvorzovskaya / Compactness and territorial integrity of the } \\
\text { allocated land area } \\
\text { Agricultural }\end{array}$ \\
\hline enterprises \\
administration
\end{tabular}

On pastures in places of ravine and gully systems development it is recommended to carry out anti-erosion measures (forest melioration): formation of shrub, forest shrub and calm forests. Such plantings are not only an additional source of food, but also create favorable conditions for grazing and prevent wind and water erosion.

The Nature Reserved Fund represented by two wildlife sanctuaries, natural monument and the State Forest Fund is recommended to preserve the natural landscapes of the Strizhament mountain; animal and plant species listed in the Red Book of the Russian Federation and Red Book of the Stavropol Region and particularly valuable in the economic, scientific and cultural relations. The main 
task of the reserve should include its assistance in the conduction of scientific research. These territories may become the basis of local monitoring of steppe vegetation and seed banks for agricultural enterprises (plant seeds to restore the natural grassland are valuable from an economic point of view).

In the framework of the transboundary State Nature Reserve it is recommended to distinguish three functional areas: the Nature Reserve Fund, rural administration and management.

The functional "Reserve" zone is intended to preserve and restore the processes of natural landscapes evolution, reference and unique natural complexes. The land plots of this zone are intended for formation of background monitoring (evaluation of soil pollution of agricultural lands, reduction of biodiversity, etc.). For example, it is recommended to allocate land plots for sowing grass seed as a basis for the pastures and hayfields improvement of agricultural enterprises. Mowing, plowing, grazing and running livestock, hunting are limited in this territory. The use, protection and reproduction of the State Forest Fund are carried out in accordance with the forestry regulations.

The functional "Agrolandscape" zone includes mainly agricultural lands (natural forage grasslands) and inarable lands. The zone is designed for agricultural activities, but environmentally friendly (traditional or innovative) methods. The zone is intended for pasture use. The allocation of three seasonal pasture areas (spring, summer, autumn-winter) was recommended (Table 2).

Table 2

Technical and economic characteristics of pastures in "Agrolandscape" area

\begin{tabular}{|c|c|c|c|}
\hline № & Pastures & \multicolumn{2}{|c|}{ Grazing areas } \\
\hline 1 & Type & summer & autumn-winter \\
\hline 2 & Vegetation type & \multicolumn{2}{|c|}{ motley grass - legume - cereal } \\
\hline 3 & $\begin{array}{l}\text { Seed requirements for improving grass } \\
\text { stand, tonnes }\end{array}$ & $12.7-13.3$ & $12.6-13.2$ \\
\hline 4 & Pasture areas, ha & 1020 & 1019 \\
\hline 5 & Size of grazing, га & \multicolumn{2}{|c|}{$25-30$} \\
\hline 6 & Pasture rotation & \multicolumn{2}{|c|}{5 fields } \\
\hline 7 & $\begin{array}{r}\text { Animal load to the area, heads: } \\
\text { sheep with lambs } \\
\text { beef cows (with calves) }\end{array}$ & $\begin{array}{c}5100-7140 \\
1530\end{array}$ & $\begin{array}{l}5033-5095 \\
1529\end{array}$ \\
\hline
\end{tabular}

To preserve the productivity of spring-summer and autumn-winter pastures it is recommended to reduce the pasture load for 1.5-2 years, where up to $50 \%$ of valuable perennial grasses remained depressed. In pasture areas, in our opinion, the most efficient is 5-field pasture rotation: $1^{\text {st }}$ year is autumn and spring seeding of perennial grass mixtures in cereals peeling; $2^{\text {nd }}$ year is spring, summer, autumn rest from grazing; $3^{\text {rd }}$ year is spring mowing for hay, combined with a moderate grazing on the aftermath of grasses with subsequent autumn, and even winter grazing; $4^{\text {th }}$ year is early spring and autumn-winter grazing; $5^{\text {th }}$ year is early spring and autumn grazing with autumn (spring) sowing grasses with transition to the new pasture rotation. In this scheme of pasture rotation, rest from grazing after sowing grass lasts for one and a half years. This allows the seedlings to take root well and obtain additional shoots due to self-examination of natural forage grasses.

For even feed intake during the season in the steppe landscapes, the duration of the grass growth period after the first grazing should be from 25 to 30 days, after the second from 35 up to 40 days and after the third from 50 up to 60 days. Therefore, depending on the specific conditions, the area of the pen can reach 25-30 ha. The main environmental standards for pasture use will contribute to: preserving the viability of valuable grass species and their productivity; uniform consumption of nutrients; seed and vegetative renewal of grass stand.

\section{Conclusions}

Thus, the post-reform agricultural transformations of the South of Russia contributed to a change in the region specialization and the decline of the livestock industry. The existing ecological and industrial instability of agricultural enterprises needs to create a new structural-functional model of land use and its ecological zoning system. 
At the moment conditions are created when it is possible to use a new environmentally sound model for spatial organization of enterprises and on its basis the State Nature Reserve. This will allow implementing the strategy of environmentally adaptive intensification of grassland ration of forage production, since the value of seeded pastures is determined by the high proportion of grassy fodder in the fodder balance (35-40\% in the unstable moistening zone) and their enormous conservation function. To stabilize the productivity of meadow phytocenoses, one should create multi-component grass stands by the type of mutually replacing species. This approach is based on the gradual successive replacement of species with a different life cycle duration, which gives a quick achievement of the species maximum productivity with low competitive ability. Consequently, environmental conditions are created for restoring and improving the vegetation of pastures in accordance with their primary steppe vegetation. Within the reserve, it is recommended to allocate three functional zones, which will ensure formation of the environmental agro-ecological framework in the form of a natural reserve fund, territories of rational nature management and rural administration.

In this regard, the strategic goal of the region is creation of livestock clusters that promote the involvement of rural areas in the innovation process. As a result, the management efficiency of agricultural land use will be based on formation of ecological normalization and economic sustainability, resource and energy efficiency, which will affect the agricultural enterprises profitability of animal husbandry. Adaptive intensification in animal husbandry will manifest itself in a more efficient use of resources, in enhancing not only production, but also the environmentimproving function of land and agrarian land use in general.

\section{References}

[1] Kulintsev V.V., Godunova E.I., Janakova L.I. etc. System of the new generation of Stavropol territory. Stavropol: AGRUS, 2013. 520 p.

[2] Effective methods of providing high-grade animal feed at the expense of field and meadow fodder production in the light of national project "Development of agriculture". Stavropol: GNU Stavropol research Institute of animal husbandry and fodder production, 2007. $75 \mathrm{p}$.

[3] Forage production in the Stavropol region: development / ed. by V. G. Grebennikov, N. S. Velikdan, V. N. Zheltovodov, A. I. Shipilov, E. D. Kush. Stavropol: SNIEC, 2014. 336 p.

[4] Kuhl S., Gauly S., Spiller A. Analysing public acceptance of four common husbandry systems for dairy cattle using a picture-based approach. Livestock science, vol. 220, 2019, pp. 196-204.

[5] Dewhurst R.J., Delaby L., Moloney A. etc. Nutritive value of forage legumes used for grazing and silage. Irish Journal of agricultural and food research, vol. 48, issue 2, 2009, pp. 167-187.

[6] Carlsson G., Martensson L.M., Prade T. etc. Perennial species mixtures for multifunctional production of biomass on marginal land. Global change biology bioenergy, vol. 9 issue 1, 2017, pp. 191-201.

[7] System of agriculture of the Stavropol region / under the General editorship of Acad. In RAS, RAAS, A. A. Zhuchenko; corresponding member cor. RAAS V. Trukhacheva. Stavropol: AGRUS, 2011. 844 p.

[8] Badgery, W.B., Michalk D.L. Synthesis of system outcomes for a grazing-management experiment in temperate native pastures. Animal production science, vol. 57, issue 9, 2017, pp. 1869-1876.

[9] Grassland: a global resource / edited D. A. McGilloway. - First published. - Netherlands : Wageningen Academic Publishers, 2005. 429 p.

[10] Utilisation of grazed grass in temperate animal systems : Proceedings of a satellite workshop of the XXth International Grassland Congress, July 2005, Cork, Ireland / edited J. J. Murphy. First published. - Netherlands : Wageningen Academic Publishers, 2005. 269 p.

[11]Esaulko A.N., Grechishkina Y.I., Sigida M.S., etc. The influence of fertilizer systems on the content of various forms of potassium and nutrition mode of humus. Oriental Journal of Chemistry, vol. 32(6), 2016, pp. 3189-3199. 